\title{
Sustainable Tourism along the Red Sea: Still Possible?
}

\author{
Amir Gohar*, G. Mathias Kondolf \\ Department of Landscape Architecture \& Environmental Planning, University of California, USA
}

Copyright $(2016$ by authors, all rights reserved. Authors agree that this article remains permanently open access under the terms of the Creative Commons Attribution License 4.0 International License

\begin{abstract}
The Red Sea is a unique resource whose potential remains underutilized. Since the $1980 \mathrm{~s}$ development for mass tourism has destroyed the northern coastal stretches as exemplified by the city of Hurghada. A number of initiatives have taken place in the past to protect areas along the Red Sea (from Marsa Alam city South), including introduction of ecotourism and coastal planning guidelines by the Red Sea Sustainable Tourism Initiative (RSSTI) in 2000-2004. Also, the "Livelihood and Income From Environment (LIFE)" program in 2005-2008 supported implementing pilot projects in national parks to demonstrate the appropriate processes. Since 2008, local NGOs (e.g; HEPCA) initiated sustainable practices such as Solid Waste Management and Mooring Buoys. Despite these initiatives, the main obstacles to improved planning and development are found to be: (i) lack of coordination within the ministry and stakeholders, (ii) lack of contextual design relevance to the Red Sea, and (iii) inappropriate land subdivisions and development in environmentally vulnerable areas. The solutions for such complex problems are summarized below: (i) Elevate land use planning above the ministry level, (ii) incorporate appropriate planning and building education, (iii) mandatory use of Land use suitability maps in the region.
\end{abstract}

Keywords Sustainable Tourism, Land Use Planning, Red Sea, Egypt

\section{Introduction}

\subsection{Background}

The Red Sea is a unique environment with deserts rich in history abutting a sea whose remarkable coral reefs are among the best in the world. With its striking environment and touristic potential, sunny climate, and short flight distance from major population centers in Europe, the Egyptian Red Sea coast has tremendous potential for economic development and benefits for the nation and region. Since this coast was opened to tourism after the Camp David
Accords of 1978, the number of hotel rooms shot up from about 40 in 1980 , to about 1890 in 1989 to about 7000 in 1999, to over 40,000 in 2009 (1). This rapid development came with unfortunate impacts on the coast and coral reefs (2).

Most of the coast is flanked by a fringing coral reef, which blocks access to deep water (3). Exceptions are the mouths of dry streams (wadis), where there are breaks in the fringing reef and commonly embayments (marsas) that offer anchorage and access to deep water for boats, snorkelling opportunities along the reef edge of the embayment, and swimming beaches along the landward shore. Thus, the best places for tourist resorts are next to marsas, with their access to snorkelling and open water. However, development has been promoted (by the Tourism Development Authority) on parcels evenly distributed along the coast; most sites are along fringing reef, where it is impossible to swim in the sea. This motivated some developers near Hurghada to physically remove the reef in front of their hotels, or to fill over the reef in attempts to create direct access to deep water; (4). While such blatant destruction is no longer common, development patterns along the coast are still not informed by the underlying carrying capacity of the coastal geomorphology, coastal waters and thus their coral reefs) have been affected by chronic pollution and are at risk of extensive contamination from flash floods that will scour waste dumps in Wadis and carry chemicals, garbage, and other pollutants out to the coral reef (5) and (6)

\subsection{Objective}

This paper aims to analyze exiting institutional structure under which development occurs in order to understand the points of deficits in the planning process. In addition, critically review the environmental planning initiatives that have taken place so far and understand their successes and failures in order to inform the decision makers of future considerations while designing or implementing such projects. And inform private developers on best practices to consider while working on new development along the Egyptian Southern area of the Red Sea coast. 
Table 1. Planning initiatives and projects in the southern regions of the Red Sea

\begin{tabular}{|c|c|c|c|c|}
\hline Project & Year & Area Cover & Lead Agency & Local Partner \\
\hline $\begin{array}{c}\text { Regional Programme for the } \\
\text { Environment of the Red Sea and Gulf } \\
\text { of Aden }\end{array}$ & 1974-1995 & Red Sea and Gulf of Aden & PERSGA & EEAA \\
\hline $\begin{array}{l}\text { UNEP Regional Seas Programme } \\
\text { Action Plan For the Conservation of } \\
\text { the Marine environment and Coastal } \\
\text { Areas of The Red Sea \& Gulf of Aden }\end{array}$ & 1976-2009 & Red Sea and Gulf of Aden & UNEP & EEAA \\
\hline Launch of Egyptian EIA & 1994-Present & Egypt & EEAA & $\begin{array}{l}\text { All other GoE } \\
\text { organizations }\end{array}$ \\
\hline $\begin{array}{l}\text { Strategic Action Programme for the } \\
\text { Red Sea \& Gulf of Aden }\end{array}$ & $1995-2003$ & Red Sea and Gulf of Aden & PERSGA & EEAA \\
\hline $\begin{array}{l}\text { Assessment and Management of } \\
\text { Mangrove Forest in Egypt for } \\
\text { Sustainable Utilization and } \\
\text { Development }\end{array}$ & $2003-2005$ & Egyptian Red Sea Coast & $\begin{array}{l}\text { Ministry of Agriculture and } \\
\text { Land Reclamation } \\
\text { (MALR), Under Secretariat for } \\
\text { Afforestation and Environment } \\
\text { (UAE) }\end{array}$ & MSEA and EEAA \\
\hline $\begin{array}{l}\text { Private Sector Tourism Infrastructure } \\
\text { and Environmental Management } \\
\text { Project }\end{array}$ & $2002-2003$ & Egyptian Red Sea Coast & World Bank & EEAA \\
\hline $\begin{array}{c}\text { Environmental Sustainable tourism } \\
\text { Project (EST) }\end{array}$ & 1998 & $\begin{array}{l}\text { Southern Region of Red } \\
\text { Sea }\end{array}$ & USAID & TDA \\
\hline $\begin{array}{l}\text { Red Sea Sustainable Tourism Initiative } \\
\text { (RSSTI) }\end{array}$ & 2001 & Egyptian Red Sea Coast & USAID & TDA \\
\hline $\begin{array}{l}\text { Livelihood \& Income From the } \\
\text { Environment (LIFE) }\end{array}$ & $2005-2008$ & $\begin{array}{l}\text { Southern Region of Red } \\
\text { Sea \& Mountains Range }\end{array}$ & USAID & $\begin{array}{l}\text { EEAA, RSG and } \\
\text { TDA }\end{array}$ \\
\hline
\end{tabular}

\section{Problem Statement}

Since the late seventies there has been recognition of the environmental significance of the Red Sea area, but attempts to do environmental planning started only in the $21^{\text {st }}$ century. Developing the Red Sea for economic reasons was mainly promoted by the Government of Egypt to create jobs and increase national income. However, efforts to implement more sustainable, environmental and balanced development were initiated by external organizations seeking to protect the ecosystem specifically the coral reef, migratory birds and mangrove trees, as well as archeological sites. These organizations include USAID, UNEP, GEF, IUCN, Italian Cooperation, UNDP and WFP. (Table 1)

The earlier projects and initiatives played a role in bringing new concepts to the attention of local authorities and were the "wake-up" call for the importance of sustainable tourism. The most recent projects are the most significant ones that took place since the beginning of this century. However, none of these initiatives were extremely successful in changing the mind set and the pattern of operation of the local authorities. The most recent two projects namely RSSTI and LIFE had sufficient funding to implement pilot examples. The RSSTI project (7) focused on the $5 \mathrm{~km}$ coastal strip of the Red Sea from Marsa Alam to Ras Banas (8), and despite all the land use planning efforts, the development continues (business as usual) after the project. The most recent project LIFE had some successful intervention with local communities' development and supported some infrastructure in the park (e.g. vehicular trails, a ranger's operation center facility, a visitor center and marine equipment).

However, none of the projects to date have achieved broad public education or developed land use suitability maps at appropriate scales to provide guidance for future ecotourism development for the area.

\section{Methods}

This research documented and overlapped current national and regional strategies that is concerned with the southern Red Sea region. In addition, mapped the governmental institutions responsible for developing the coast.

Through interviews with officials in the environmental agencies (EEAA), the tourism agencies (TDA) and the local governorates (RSG) and in addition to 8 years of experience in international development projects in the Red Sea area, the exiting framework of development was analyzed. This paper highlights areas of potential improvements towards improved sustainable tourism planning. In addition, the overall scheme of design and planning templates for the coast was analyzed. Based on these investigations, a comprehensive set of recommendations were put to gather to address each of the findings on both the right scale and the appropriate institutional level.

\section{Findings}

Despite the thorough attempts of environmental planning agencies, and despite the fact that there is more awareness 
about environmental planning and ecotourism planning, the pattern of land subdivisions remains inappropriate for the environment. The reasons can be summarized as follows:

\subsection{Current Structure of Government Agencies}

The implementing agencies for tourism planning, in general, are subordinate agencies to Ministries and have specific mandate that often prevent planners from examining issues from a multidisciplinary perspective. A national or regional planning agency with a broader perspective could alleviate this problem. Alternatively, elevating the authority (or jurisdiction) of individual planning agencies would also encourage multidisciplinary planning perspectives. A schematic simplified diagram for the existing ministries and some of their executing arms has been shown in figure (1).

The selected ministries and subordinating agencies in table 2 are examples of ministries that shape/influence development across the country including the development of the Red Sea region.

The Tourism Development Authority (TDA) under the Ministry of Tourism has a very well-defined mandate, consisting of dividing the land, and encouraging developers to invest in tourism facilities to increase the number of rooms and therefore attract more tourism. They have been successful in achieving the target. However, TDA has not fully considered its impact on environmental resources and fragile ecosystems, so achieving this development was at a very high environmental cost.

Table 2. Example of a number of ministries and their subordinate agencies.

\begin{tabular}{|c|c|}
\hline Ministry & Implementing Agencies (subordinate agencies). \\
\hline Tourism & Tourism Development Authority and Tourism Promotion Authority \\
\hline Environment & Egyptian Environmental Affairs Agency, Shore line Protection Agency \\
\hline Housing & General Organization for Physical Planning, New Unban Communities Authorities \\
\hline Culture & Supreme Commission for Antiquities \\
\hline
\end{tabular}

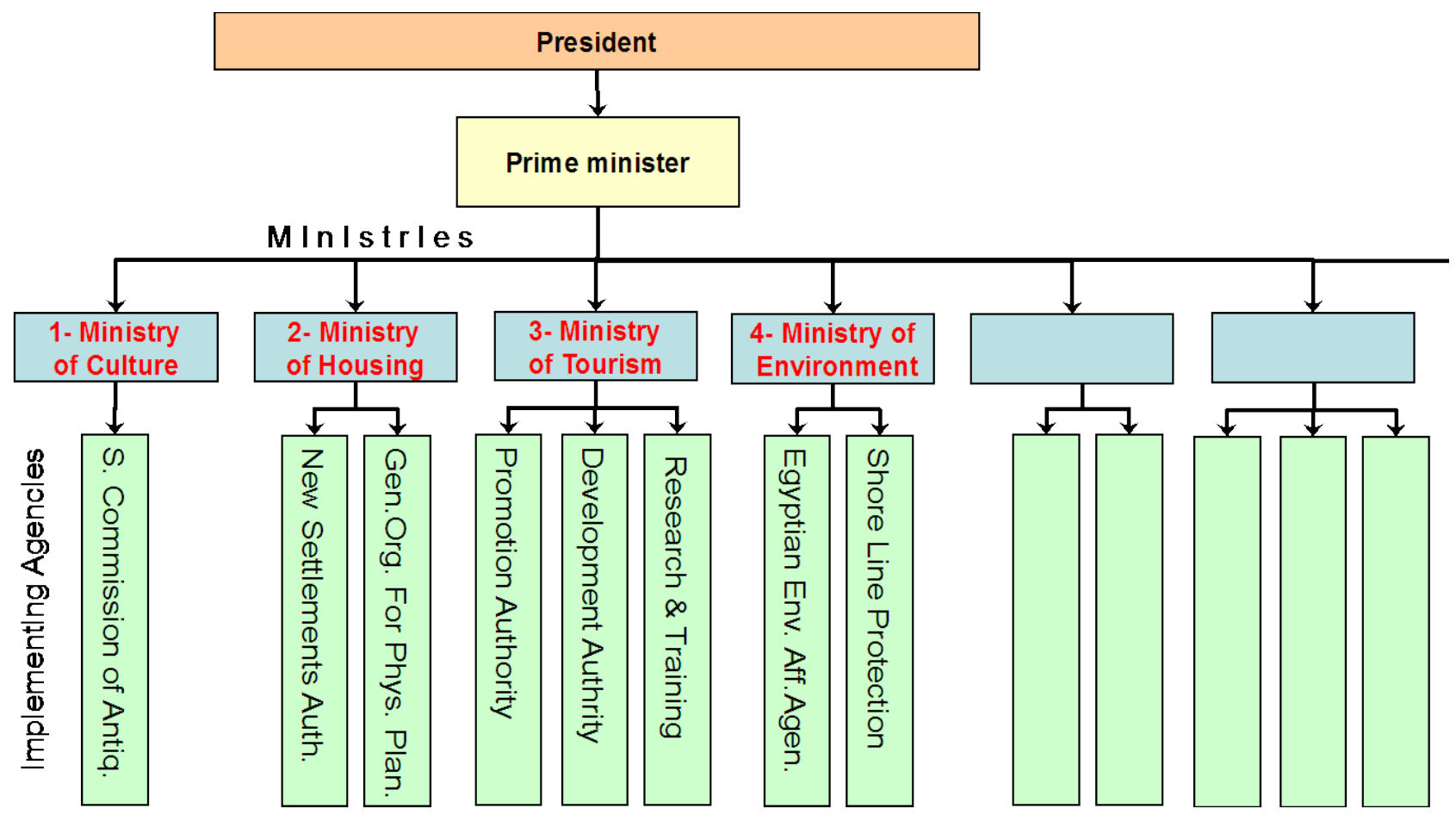

Figure 1. Schematic structure of existing government organizations 


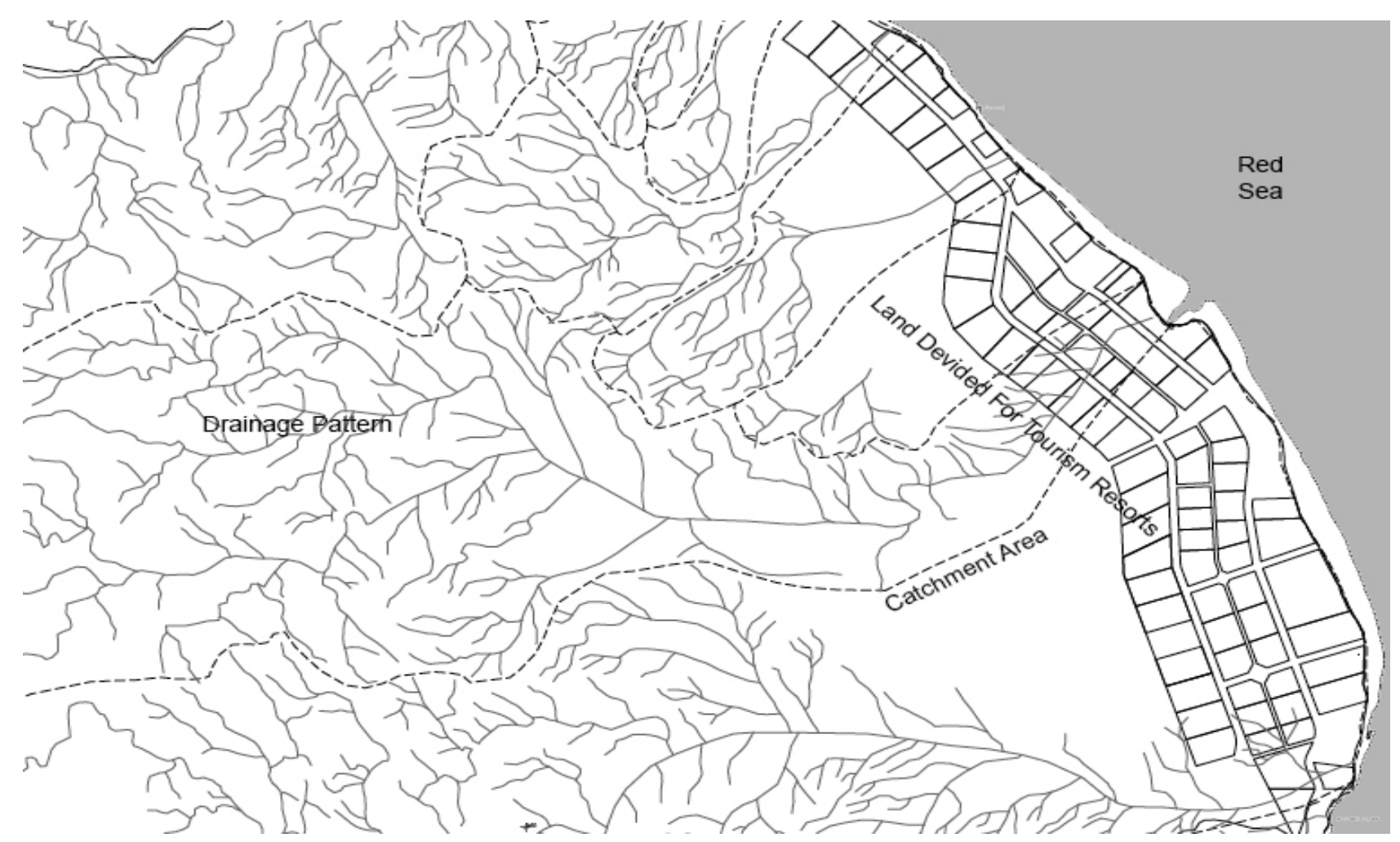

Figure 2. Existing coastal land subdivision for tourism facilities in the Red Sea. The map shows the planning in relation to shoreline, coastal highway and drainage pattern

\subsection{Current Methods for Planning \& Design}

Even within the available small window that international organizations promote to introduce some environmental planning for such a quality destination, the actual attempts have been lacking sufficient information about sustainability. The planning process did not recognize the weight of the environmental and cultural factors. Although some projects had high level of awareness about the appropriate planning, this was on the ideas and concept level and was not carried out forward to implementation. The typical planning techniques adopted further north (which is land subdivisions in linear row) has continued to be used in the southern region of the Red Sea. (Figure 2)

\subsection{Planning \& Design Models}

The local residents in the area are nomads who move across the Red Sea mountain range. Their numbers are small and their settling points within this migratory network tend to be fresh water wells where they practice grazing, and small villages near the shoreline where their main activity is fishing. Therefore, their physical traces are less impressive than the architecture dominating other parts of Egypt.

Most of the professional planning and design attempts to "go-green" have been imported from other climates. While perhaps environmentally friendly and useful for their original settings, they may not be appropriate for the Red Sea coast of Egypt. The following are two examples of this practice:

\section{- Copying Nile Valley Development Style}

Architects and landscape architects in Egypt are heavily influenced by the architecture of the Nile Valley, and have drawn upon the vernacular architecture and building materials of the Nile for building along the Red Sea. However the Nilotic template is not necessarily the most appropriate for the Red Sea desert, climate, soil, available stone, economic activity and nature of residents. Patterns of life in the eastern desert of Egypt are very different and would suggest different patterns of planning and design for the coast. Figures 2 and 3 show some replication of domes and vaults using concrete. (Vaults and domes are originally structure forms that are suitable for areas like Nile valley where mud bricks and limestone exist).

\section{- Copying Other External Development Style}

In attempts to replicate successful examples of world class ecotourism, such as South Africa "Ecolodges", the tendency has been to replicate the facility rather than the planning and design process, which resulted in, ignoring differences in locally available material, climate and other aspects. Figure 4 shows an example of the building style of one of the camps using wood and concrete while the area is rich in other material that can be of more use such as granite and gravel. 


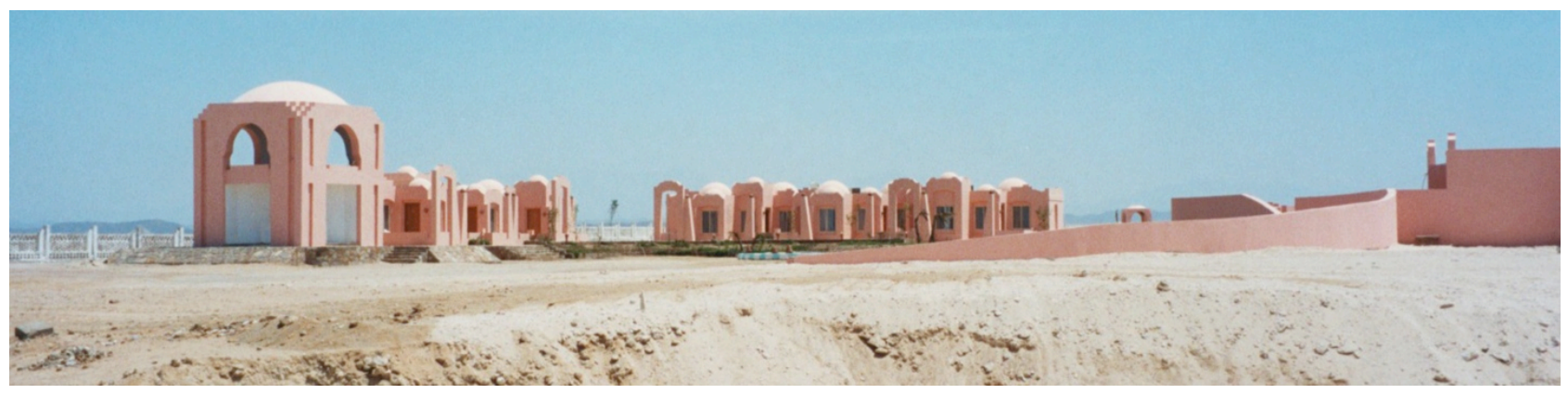

Figure 3. Tourism facility (Al-Zabargad) in the Red Sea coast.

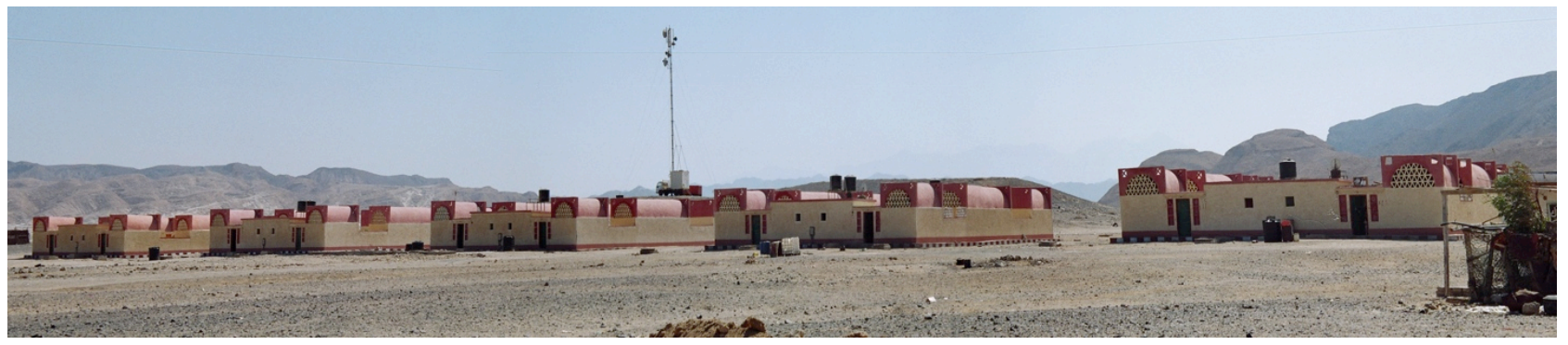

Figure 4. The government Housing (in Hamata Village) for local residents is not suitable for climate, locals' needs, design or internal zoning. It has remained unoccupied since it was built (Source, several interviews with local tribes - 2003-2007)

\section{Discussion}

TDA's approach of dividing up coast lands into regularly spaced parcels cannot take into account the very different context of each land at different parts of the coast. Moreover, the TDA's mandate to develop has been manifested more in quantity than quality of tourism (i.e. number of rooms or nights versus revenue), resulting in densely developed coasts in the northern part of the Red Sea with a very low selling rate per room per night (goes as low as $12 \$ /$ night in charter flights packages). This resulted in a mass tourism which created stress on environmental assets and significant environmental degradation such as developing on landfill, destruction of coral reef, pressure on fresh ground water, development within flood zones and a reduction in quality of the destination.

International Environmental Planning initiatives have achieved little individual successes in areas such as effective use of water, grey water recycle, waste disposal, however, they most importantly highlight the issue of sustainability and bring it to the attention of the Egyptian government as well as private developers.

The current practice of employing the design templates of the Nile valley architecture and other global inappropriate examples has stifle the development of a building style that is in direct conflict with the coastal environmental and cultural context.

The gap between what is implemented in terms of sustainability measure and what is envisioned for this region remains very big, and both the Egyptian government and the international planning initiative shall push sustainable development further in the planning process and in the implementation of such tourism projects.

\section{Recommendations}

\subsection{Institutional Improvements}

\section{- Institutional restructure}

It is recommended that planning authorities be elevated above the single sector ministries to avoid the current conflicts between the Ministry of Tourism (aiming to increase tourism development) and the Ministry of Environment (aiming to preserve environmental resources). Figure 5 shows a proposal to elevate the planning authorities above the ministries as agencies that serve one sector through formulation of a cross-cutting higher commission for planning. This is a proposal developed by "Mithaq Group", a group of professionals representing several organizations, and supported by several political parties and civil society organizations

\section{- Implementation agency mandate}

Like any other ministry in Egypt, the Ministry of Tourism is supported by many implementing arms such as: Tourism Development Authority, Tourism Promotion Agencies and others.

It is recommended that the objective of Tourism Development authority to be changed from "Mass" tourism, where success is evaluated by the number of hotel rooms built, to low, moderate or "eco" tourism (achieving more number of rooms built) to "Moderate" or "eco" tourism (achieving same revenue or more with less number of rooms). Figure 7 shows the major difference between current planning approaches and alternative concepts:

a) The current parcelization pattern (alternative A) 
tends to block natural flooding paths, reduce public view of the sea, minimize monitoring and limit control over the marine activities

b) Laying out parcels in groups (alternative B) allows for floods to flow smoothly without damage, guarantees better management, more and beneficial environmental monitoring, exclusivity and better sustainability for the existing resources

c) Alternative (C) proposes a more integrated and exclusive pattern that is economically feasible, safe from floods and provides better protection for the environment

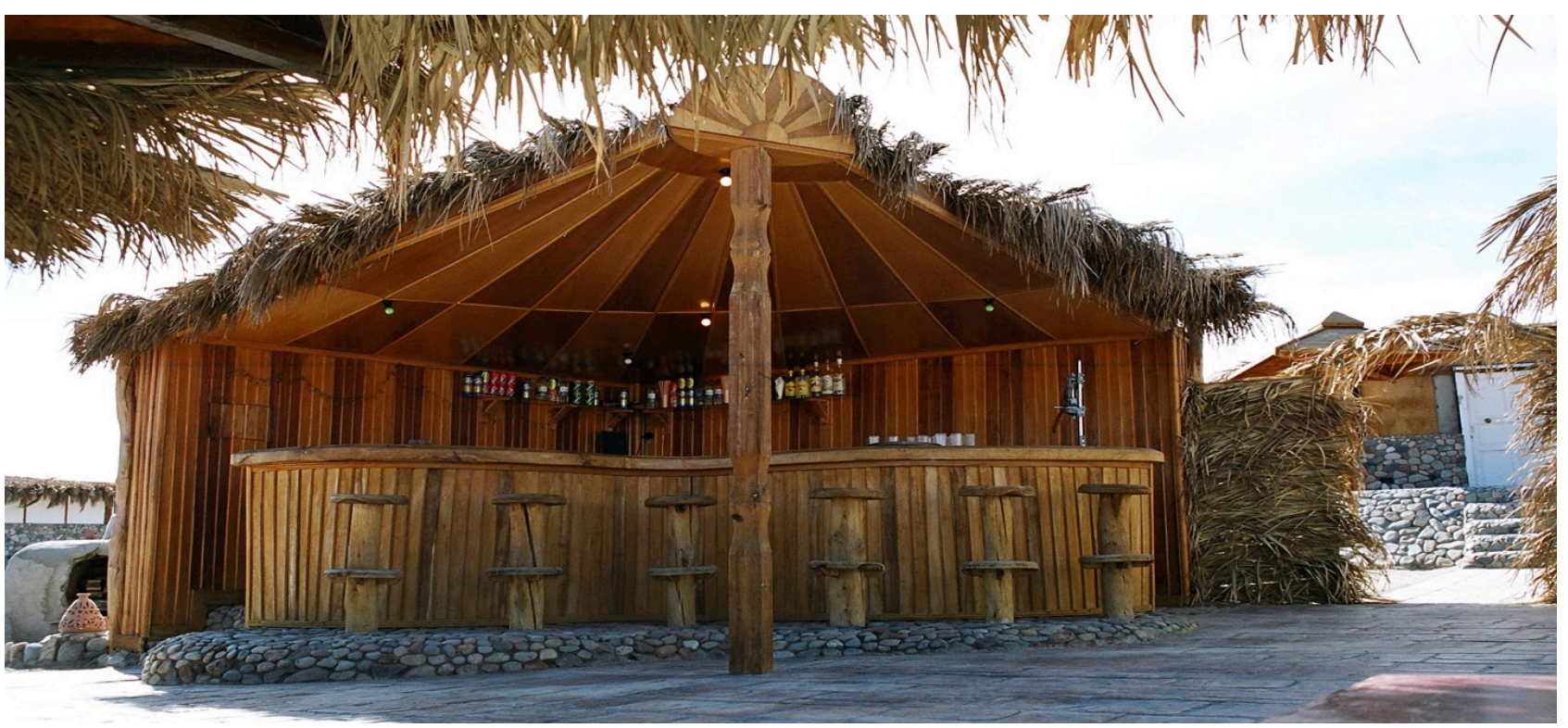

Figure 5. Inspired by South African lodges, using (wood) in the construction of some coastal facilities, where wood is an extremely rare material and not local

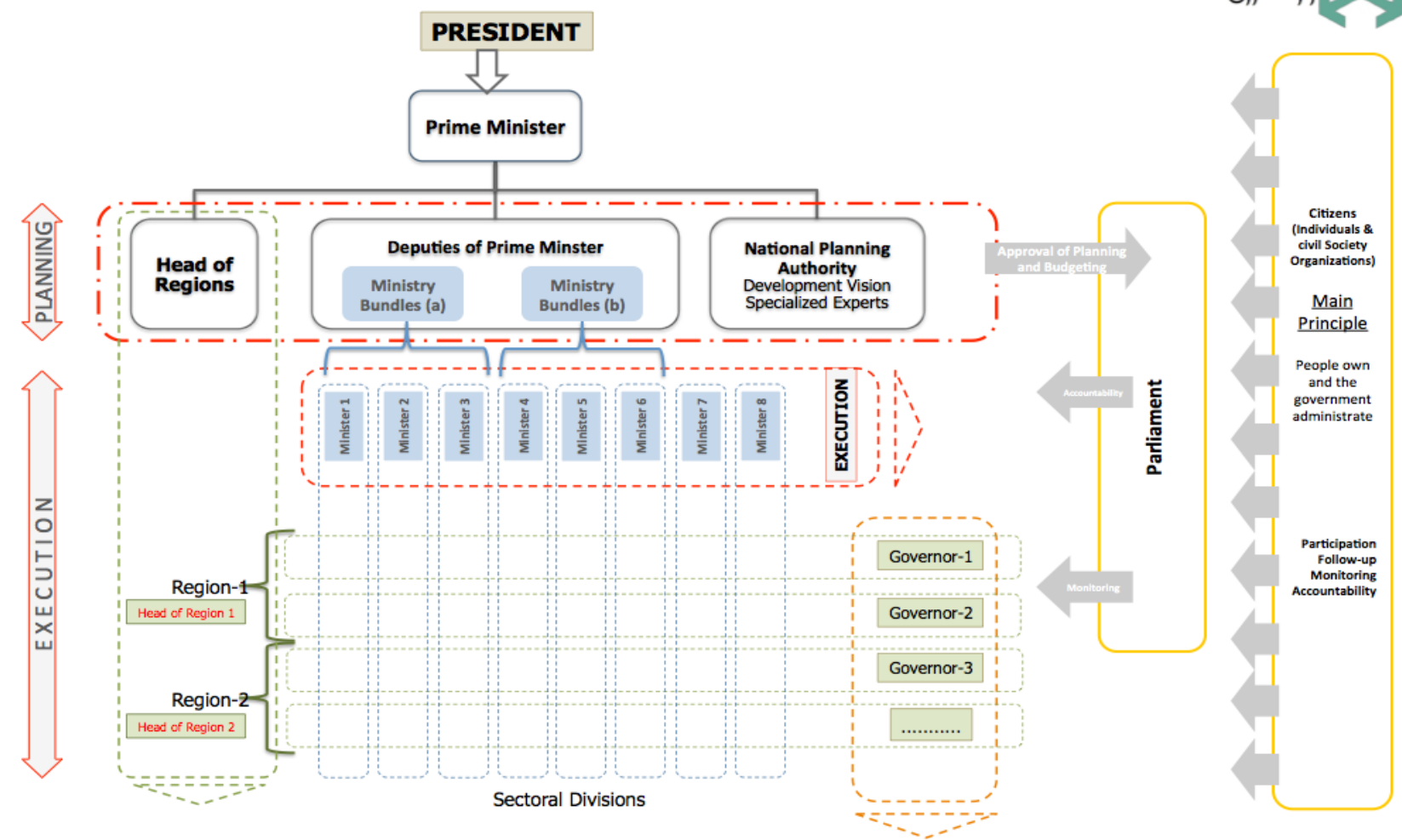

Figure 6. Proposed schematic restructure for the government (proposed for the new constitution) as part of the current formulation of the government after the $25^{\text {th }}$ of January revolution (developed be the "Mithaq Group") 

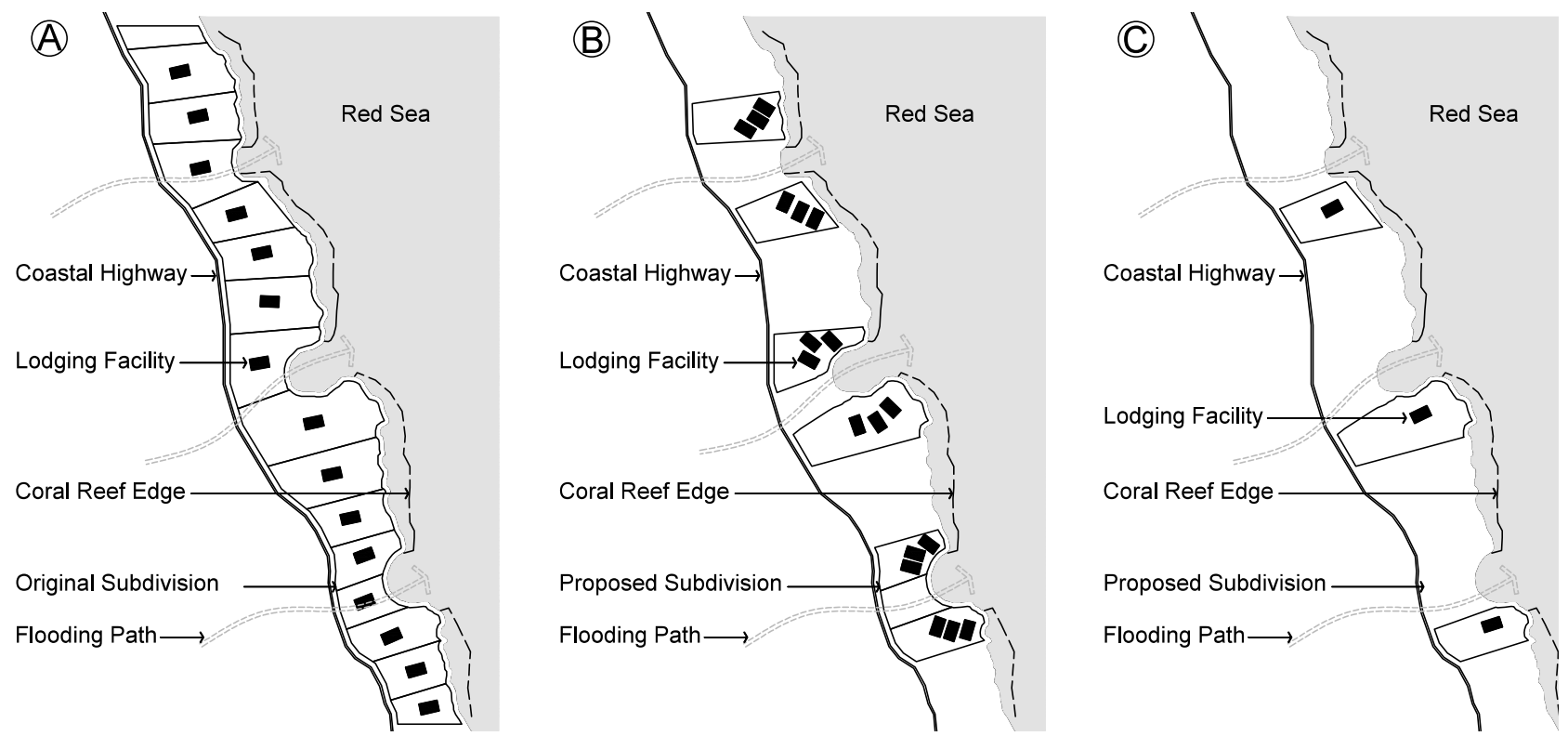

Figure 7. (a) Convention planning, (b) alternative concept with the same numbers of rooms, (c) low intensity development with focus on higher exclusive facility

\subsection{Improve Environmental Planning \& Design Capabilities}

(a) Planning Level

The local authority (TDA) responsible for this planning will need to conduct a comprehensive research project to help identify vulnerability maps to inform other government agencies and developers of potential hazards in the region. It is also crucial to re-evaluate the planning process for the coastal area and incorporate a higher environmental planning component.

Informing the public and the investor of accurate potentials and hazards of sites is a key element to shaping the development pattern for the region and will help reduce risks that may occur to people and investments.

Increasing the technical capabilities for the planning team about Integrated Coastal Zone Management, (ICZM) will allow them to plan the coastal plain in conjunction and proper integration with the mountain deep range of the Red Sea, because the ecosystem is interlinked and the coast cannot be sub divided in isolation of what is going neither in the deep desert (west) nor on the marine side (east).

\section{(b) Design Level}

It is important to pay closer attention to the designs proposed by project developers and to re-evaluate the entire site layout to make sure it falls within the planning principles and ecological considerations on the macro scale. This can be achieved by revisiting the current Environmental Impact Assessment (E.I.A) process for such projects to include wider zones than the projects land lot.
One important consideration in tourism planning relate to adopting design solutions within the site boundaries, such as avoiding building in Wadi floor, using light structural development in potential runoff zones and avoiding locating facilities in parts of land where there is potential for flooding or soil replacement. This requires selecting competent landscape designers who are able to understand the site and respond to the developer needs without harmful designs that end up with environmental disasters.

The environmental regulations and current practices for shoreline setback are developed in isolation of risks that may occur from shoreline dynamics such as seal level change, realization of different habitat basic needs (e.g. turtle nesting sites and coastal mangrove zones).

\subsection{Improving Education \& Learning from Local Knowledge}

It is recommended to conduct consultation with local residents about their experience with ecological factors in the area. Such consultation will provide insights to numerous factors that might not otherwise be evident during the decision making time such as history of previous floods, types of winds in other seasons, project impact on local flora and network of movement for the fauna system (migratory birds and camel trail systems).

This consultation could include a wide range of public participation, engaging the nomads in the planning process and allowing for a communication channel between the developer and local residents in the Red Sea region. 


Abbreviations
\begin{tabular}{|c|c|}
\hline EEAA & Egyptian Environmental Affairs Agency \\
\hline GEF & Global Environmental Facility \\
\hline GOPP & General Organization for Physical Planning \\
\hline LIFE & Livelihood and Income From the Environment \\
\hline MALR & Ministry of Agriculture and Land Reclamation \\
\hline MOT & Ministry of Tourism \\
\hline MSEA & Ministry of State for Environmental Affairs \\
\hline PERSGA & Organization for the Conservation of the Environment of the Red Sea and Gulf of Aden \\
\hline RSG & Red Sea Governorate \\
\hline RSSTI & Red Sea Sustainable Tourism Initiative \\
\hline TDA & Tourism Development Authority \\
\hline TPA & Tourism Promotion Authority \\
\hline UNEP & United Nation Environmental Program \\
\hline USAID & United States Agency for International Development \\
\hline WFP & World Food Program \\
\hline
\end{tabular}

\section{REFERENCES}

[1] Report. Egyptian Minitry of Tourism. 2009.

[2] Dewidar KM. Landfill detection in Hurghada, North Red Sea, Egypt, using Thematic Mapper images. 2002;1161(January).

[3] Foody GM, Ghoneim EM, Arnell NW. Predicting locations sensitive to flash flooding in an arid environment. 2004;292:48-58.

[4] Frihy O, Dewidar K, El-Raey M. Evaluation of coastal problems at Alexandria, Egypt. 1996;30(95):281-95.

[5] Ismail I. Coral Reef Stress Risk Analysis: Incorporating Choices of Coastal Development Design and Infrastructure

Technologies. 2003.

[6] Radke J, Kondolf GM, Ismail I. Mitigating risks to coral reefs from land derived contaminants: results of studies in the Caribbean and applications to wadi flooding on the Egyptian Red Sea coast. In Proceedings of the PERSGA Sea to Sea Second Regional Forum; 2005.

[7] Tourism-Development-Authority, Red-Sea-Sustainable-Tourism-Initiative-(RSSTI). Best practi ces for solid waste management in Red Sea tourism centers. 2004.

[8] USAID, PA-Consulting-Group, Chemonics-International. Enhancing Sustainable Tourism in the Southern Red Sea Region of Egypt. 2008.

[9] Abdelhalim K, Abu-Samra M, El-Setouhy H, Gohar A, Ibrahim N, Khairy T, et al. Urban Manifesto of Egypt. 2012. 